DOI: $10.19195 / 0137-1134.106 .15$

MICHAŁ RADUŁA

Uniwersytet Wrocławski

\title{
KOMPETENCJE WOJEWODY W STOSUNKU DO PODMIOTÓW LECZNICZYCH W STANACH NADZWYCZAJNYCH
}

Wprowadzanie stanów nadzwyczajnych wiąże się z występowaniem szczególnych zagrożeń, także dla życia i zdrowia ludzkiego. W obowiązującym kształcie ustawodawstwa działalność z zakresu ochrony zdrowia wykonywana jest w szczególności przez podmioty lecznicze. Niniejsza publikacja stanowi próbę syntezy kompetencji wojewody w odniesieniu do tych podmiotów w okresie trwania stanów nadzwyczajnych.

\section{ZADANIA PUBLICZNE Z ZAKRESU OCHRONY ZDROWIA}

Ustrój państwowy Rzeczypospolitej Polskiej opiera się na trójpodziale władzy ustawodawczej, wykonawczej i sądowniczej, które wzajemnie się równoważą. Organami władzy ustawodawczej są Sejm i Senat, wykonawczej — Prezydent RP wraz z Radą Ministrów, natomiast sądy i trybunały stanowią emanację władzy sądowniczej. Na mocy przepisów Konstytucji RP w stosunku do wszelkich organów władzy publicznej aktualna pozostaje zasada związania prawem - podejmowania działania na podstawie $\mathrm{i}$ w granicach powszechnie obowiązującego prawa ${ }^{1}$.

Zadania z zakresu ochrony zdrowia wykonywane są przez wymienione organy, ministrów (przede wszystkim ministra właściwego do spraw zdrowia), centralne organy administracji rządowej, wojewodów, jednostki samorządu terytorialnego, a także przez samorządy zawodów medycznych. Realizacja zadań następuje przez określanie sposobu funkcjonowania systemu ochrony zdrowia (zadania regulacyjne), pełnienie funkcji organizatora udzielania świadczeń zdrowotnych (zadania organizatorskie), a także przez ich finansowanie (zadania płatnika). Ponadto normy prawne w sferze ochrony zdrowia tworzą podział na

${ }^{1}$ Art. 7 i 10 Konstytucji Rzeczypospolitej Polskiej z dnia 2 kwietnia 1997 r., Dz.U. Nr 78, poz. 483 ze zm. 
zadania o charakterze administracji reglamentacyjno-porządkowej (kontrola i nadzór) i zadania administracji świadczącej (udzielanie świadczeń zdrowotnych)².

\section{ZADANIA PUBLICZNE WOJEWODY Z ZAKRESU OCHRONY ZDROWIA}

Organami administracji rządowej w województwie są wojewoda, rządowa administracja zespolona $\mathrm{w}$ województwie (wraz z kierownikami zespolonych służb, inspekcji i straży) oraz organy administracji rządowej niezespolonej. Zadania z zakresu administracji rządowej mogą być także wykonywane przez jednostki samorządu terytorialnego lub ich związki, gdy przepis szczególny przewiduje taką możliwość lub zostało zawarte stosowne porozumienie. Nadto wykonywanie zadań administracji rządowej może być powierzone na mocy odrębnych ustaw staroście, a także innym podmiotom przewidzianym prawem ${ }^{3}$.

W kontekście regulacji z zakresu opieki zdrowotnej wojewoda wykonuje zadania administracji rządowej (uwzględniając właściwość terytorialną) z działu „zdrowie”. Ustawa o działach administracji rządowej ${ }^{4}$ porządkuje bowiem poszczególne zadania publiczne wedle ich rodzaju. Dział „zdrowie” obejmuje w szczególności ochronę zdrowia i jej organizację, sprawowanie nadzoru nad produktami leczniczymi i wyrobami medycznymi, organizację Państwowego Ratownictwa Medycznego, organizację i realizację funkcji nadzorczej nad wykonywaniem zawodów medycznych, inspekcję sanitarną, lecznictwo uzdrowiskowe, a ponadto część regulacji w przedmiocie koordynacji ubezpieczenia zdrowotnego (art. 33 ust. 1 pkt 1-8 UDARz).

Realizacja przez wojewodę zadań następuje w formie decyzji i zarządzeń, co więcej - na rzecz wojewody zastrzeżone zostało domniemanie kompetencji spraw z zakresu administracji rządowej (na właściwym terytorium). Wojewoda reprezentuje skarb państwa w sposób przewidziany prawem, a także jest przedstawicielem Rady Ministrów w województwie. W aspekcie prawa proceduralnego wojewoda jest organem wyższego stopnia w rozumieniu k.p.a. Rozważając problematykę zadań z zakresu ochrony zdrowia, trzeba podkreślić, że wojewoda jest zwierzchnikiem w stosunku do organów rządowej administracji zespolonej w województwie. Wojewoda kieruje, koordynuje, kontroluje oraz gwarantuje uwarunkowania sprzyjające skutecznej działalności tych organów. Ponadto pozostaje organem odpowiedzialnym za poziom efektywności prowadzonej przez te organy działalności (w obrębie opieki zdrowotnej będzie to przede wszystkim inspekcja

2 Por. M. Dercz [w:] Prawo publiczne ochrony zdrowia, red. M. Dercz, Warszawa 2013, s. 47-51, więcej w kontekście funkcji regulatora, organizatora i płatnika - s. 60-65, 76, 82.

3 Art. 2 ustawy z dnia 23 stycznia 2009 r. o wojewodzie i administracji rządowej w województwie, tekst jedn. z dnia 20 marca 2015 r., Dz.U. z 2015 r., poz. 525 (dalej: UWoj.).

${ }^{4}$ Ustawa z dnia 4 września 1997 r. o działach administracji rządowej, tekst jedn. z dnia 8 kwietnia 2016 r., Dz.U. z 2016 r., poz. 543 (dalej: UDARz). 
sanitarna i farmaceutyczna). Jednocześnie wojewoda jest organem nadzorczym — również w realizacji zadań opieki zdrowotnej — gdy idzie o działalność jednostek samorządu terytorialnego oraz ich związków. Nadzór obejmuje badanie działalności pod względem legalności, z zastrzeżeniem, że w ramach realizacji zadań z zakresu administracji rządowej na mocy przepisu ustawy lub właściwego porozumienia z organami administracji rządowej nadzór obejmuje obok kryterium legalności także aspekt rzetelności i gospodarności (art. 3 ust. 1 i 2 i art. 51 UWoj. $)^{5}$. Wojewoda jest także organem prowadzącym rejestr podmiotów wykonujących działalność leczniczą. Wpisowi do rejestru prowadzonego przez wojewodę podlegają podmioty, które mają na terytorium danego województwa siedzibę albo miejsce zamieszkania ${ }^{6}$.

Ponadto wojewoda ma kompetencje do stanowienia (na podstawie i w granicach upoważnienia ustawowego) w zakresie spraw opieki zdrowotnej aktów prawa miejscowego. Mogą one obowiązywać w części lub na całym terytorium województwa. W przypadku konieczności ochrony życia i zdrowia ludzkiego wojewoda wydaje rozporządzenia porządkowe. Dla kwestii ochrony zdrowia newralgiczny pozostaje obowiązek wojewody w postaci gwarancji kooperacji organów administracji rządowej oraz organów administracji samorządowej, jak również pełnienie funkcji kierowniczej nad działalnością tych organów w sferze przeciwdziałania ewentualnym zagrożeniom życia i zdrowia ludzkiego. Warto wspomnieć, że wojewoda wykonuje, koordynuje i kontroluje politykę Rady Ministrów w województwie, zatem także politykę zdrowotną ${ }^{7}$.

\section{PODMIOTY LECZNICZE}

Przepisy UDL regulują w szczególności zasady wykonywania działalności leczniczej, a także prawa i obowiązki podmiotów leczniczych. Podmiotami leczniczymi na gruncie ustawy są przede wszystkim:

1) przedsiębiorcy w rozumieniu ustawy z dnia 2 lipca 2004 r. o swobodzie działalności gospodarczej ${ }^{8}$,

2) samodzielne publiczne zakłady opieki zdrowotnej (dalej: SPZOZ-y),

3) jednostki budżetowe,

4) instytuty badawcze,

5 Więcej M. Dercz, op. cit., s. 130-131.

${ }^{6}$ Art. 106 ust. 1 pkt 1 ustawy z dnia 15 kwietnia 2011 r. o działalności leczniczej, tekst jedn. z dnia 8 kwietnia 2015 r., Dz.U. z 2015 r., poz. 618 ze zm. (dalej: UDL).

7 Zob. więcej o kompetencjach wojewody M. Mazuryk, [w:] Administracja publiczna. Ustrój administracji państwowej terenowej. Komentarz, red. K. Miaskowska-Daszkiewicz, B. Szmulik, s. 32-40; S. Pieprzny, Administracja bezpieczeństwa i porządku publicznego, Rzeszów 2014, s. 82-85.

${ }^{8}$ Ustawa z dnia 2 lipca 2004 r. o swobodzie działalności gospodarczej, tekst jedn. z dnia 8 kwietnia 2015 r., Dz.U. 2015 r. poz. 584 ze zm. (dalej: USDG). 
5) fundacje,

6) stowarzyszenia9 ${ }^{9}$.

Wymienione podmioty kwalifikowane są jako podmioty lecznicze w zakresie, w jakim wykonują działalność leczniczą, która w szczególności polega na udzielaniu świadczeń zdrowotnych — działań służących profilaktyce, zachowaniu, ratowaniu, przywracaniu lub poprawie zdrowia oraz innych działań medycznych wynikających z procesu leczenia lub przepisów odrębnych regulujących zasady ich udzielania (art. 3 ust. 1 UDL w zw. z art. 5 pkt 40 ustawy z dnia 27 sierpnia 2004 r. o świadczeniach opieki zdrowotnej finansowanych ze środków publicznych ${ }^{10}$ ). Działalność lecznicza obejmuje także aktywność w obszarze promocji zdrowia lub realizacji zadań dydaktycznych i badawczych w powiązaniu z udzielaniem świadczeń zdrowotnych i promocją zdrowia, w tym wdrażaniem nowych technologii medycznych lub metod leczenia (art. 3 ust. 2 pkt 1 i 2 UDL). Warto zaznaczyć, że działalność lecznicza może być wykonywana także za pośrednictwem systemów teleinformatycznych lub systemów łączności ${ }^{11}$. Podkreślenia wymaga też, że działalność lecznicza - z nielicznymi wyjątkami — jest kwalifikowaną działalnością gospodarczą - działalnością regulowaną (art. 16 ust. 1 UDL) ${ }^{12}$.

9 Art. 4 ust. 1 UDL: Podmiotami leczniczymi są:

1) przedsiębiorcy w rozumieniu przepisów ustawy z dnia 2 lipca 2004 r. o swobodzie działalności gospodarczej (Dz.U. z 2015 r., poz. 584) we wszelkich formach przewidzianych dla wykonywania działalności gospodarczej, jeżeli ustawa nie stanowi inaczej;

2) samodzielne publiczne zakłady opieki zdrowotnej;

3) jednostki budżetowe, w tym państwowe jednostki budżetowe tworzone i nadzorowane przez Ministra Obrony Narodowej, ministra właściwego do spraw wewnętrznych, Ministra Sprawiedliwości lub szefa Agencji Bezpieczeństwa Wewnętrznego, posiadające w strukturze organizacyjnej ambulatorium, ambulatorium z izbą chorych lub lekarza, o którym mowa w M. Dercz, T. Rek, Ustawa o działalności leczniczej. Komentarz, Warszawa; art. 55 ust. 2a ustawy z dnia 27 sierpnia 2004 r. o świadczeniach opieki zdrowotnej finansowanych ze środków publicznych, Dz.U. z 2015 r., poz. 581;

4) instytuty badawcze, o których mowa w art. 3 ustawy z dnia 30 kwietnia 2010 r. o instytutach badawczych, Dz.U. Nr 96, poz. 618 , z późn. zm.;

5) fundacje i stowarzyszenia, których celem statutowym jest wykonywanie zadań w zakresie ochrony zdrowia i których statut dopuszcza prowadzenie działalności leczniczej;

5a) posiadające osobowość prawną jednostki organizacyjne stowarzyszeń, o których mowa w pkt 5;

6) osoby prawne i jednostki organizacyjne działające na podstawie przepisów o stosunku państwa do Kościoła katolickiego w Rzeczypospolitej Polskiej, o stosunku państwa do innych kościołów i związków wyznaniowych oraz o gwarancjach wolności sumienia i wyznania;

7) jednostki wojskowe.

10 Ustawa z dnia 27 sierpnia 2004 r. o świadczeniach opieki zdrowotnej finansowanych ze środków publicznych, tekst jedn. z dnia 8 kwietnia 2015 r., Dz.U. z 2015 r., poz. 581 (dalej: UŚP).

11 Zob. przepisy ustawy z dnia 9 października 2015 r. o zmianie ustawy o systemie informacji w ochronie zdrowia oraz niektórych innych ustaw (Dz.U. z 2015 r., poz. 1991), dostosowujące kształt ustawodawstwa do możliwości udzielania świadczeń zdrowotnych na odległość — usług telemedycznych.

12 Działalnością regulowaną, czyli działalnością gospodarczą, której wykonywanie wymaga spełnienia szczególnych warunków określonych przepisami prawa — art. 5 pkt 5 USDG. 
Istotne jest, aby odróżnić podmioty lecznicze od podmiotów wykonujących działalność leczniczą. Te ostatnie zawierają szerszy zakres podmiotowy, albowiem oprócz podmiotów leczniczych jako podmioty wykonujące działalność leczniczą kwalifikowani są lekarze i pielęgniarki, wykonujący zawód w ramach działalności leczniczej jako praktykę zawodową (art. 2 ust. 1 pkt 5 UDL) ${ }^{13}$.

\section{KOMPETENCJE WOJEWODY Z ZAKRESU OCHRONY ZDROWIA W STANACH NADZWYCZAJNYCH}

Stany nadzwyczajne mogą zostać wprowadzone w sytuacjach szczególnych zagrożeń, gdy zwykłe środki konstytucyjne okażą się niewystarczające. Ze względu na typ zagrożenia stany nadzwyczajne występują w formie stanu wojennego, stanu wyjątkowego i stanu klęski żywiołowej ${ }^{14}$. Omawiana problematyka koreluje najsilniej ze stanem wojennym i stanem klęski żywiołowej, zatem dalej zostaną zaprezentowane regulacje dotyczące tych dwóch stanów.

\section{KOMPETENCJE WOJEWODY Z ZAKRESU OCHRONY ZDROWIA W STANIE WOJENNYM}

Stan wojenny wprowadza (na części lub na całym terytorium państwa) Prezydent Rzeczypospolitej Polskiej na wniosek Rady Ministrów. Przesłanką jego wprowadzenia jest zewnętrzne zagrożenie państwa, w tym spowodowane działaniami o charakterze terrorystycznym lub działaniami w cyberprzestrzeni, zbrojna napaść na terytorium Rzeczypospolitej Polskiej lub gdy z umowy międzynarodowej wynika zobowiązanie do wspólnej obrony przeciwko agresji ${ }^{15}$.

W czasie stanu wojennego wolności i prawa człowieka i obywatela mogą ulec ograniczeniom, a podlegają im wszystkie osoby fizyczne zamieszkałe lub przebywające choćby tymczasowo na obszarze, na którym został wprowadzony stan wojenny, a także wszystkie osoby prawne i jednostki organizacyjne nieposiadające osobowości prawnej mające siedzibę lub prowadzące działalność na obszarze objętym stanem wojennym (art. 18 ust. 1 USWoj.). Zakres wprowadzanych ograniczeń nie jest dowolny, Konstytucja RP definiuje katalog ograniczeń w sposób negatywny, wskazując, jakie wolności i prawa nie mogą być przedmiotem ograniczenia

13 Zob. więcej A. Fiutak, Prawo w medycynie, Warszawa 2011, s. $31 \mathrm{n}$.

14 Art. 228 ust. 1 Konstytucji RP (dalej: KRP); zob. więcej B. Banaszak, Konstytucja Rzeczypospolitej Polskiej. Komentarz, Warszawa 2012, s. 1086-1113; W. Skrzydło, Konstytucja Rzeczypospolitej Polskiej. Komentarz, Warszawa 2009, s. 285-294; więcej w ujęciu teoretycznym L. Mażewski, Bezpieczeństwo publiczne. Stany nadzwyczajne w Rzeczypospolitej Polskiej oraz Polskiej Rzeczypospolitej Ludowej 1918-2009, Toruń 2010, s. 229-255.

15 Art. 2 ust. 1 ustawy z dnia 29 sierpnia 2002 r. o stanie wojennym oraz o kompetencjach Naczelnego Dowódcy Sił Zbrojnych i zasad jego podległości konstytucyjnym organom Rzeczypospolitej Polskiej, tekst jedn. Dz.U. z 2016 r., poz. 851 (dalej: USWoj.). 
w trakcie trwania stanu wojennego (art. 233 ust. 1 i 2 KRP). Ponadto stanowione ograniczenia muszą być zgodne z zasadą celowości i proporcjonalności wprowadzania stanów nadzwyczajnych. Celem wprowadzania określonych restrykcji powinno być przywrócenie normalnego funkcjonowania państwa, a charakter ograniczeń powinien odpowiadać stopniowi zagrożenia (art. 18 ust. 2 USWoj. w zW. z art. 228 ust. 5 KRP) $)^{16}$.

Jedną z wolności, która może zostać ograniczona w trakcie trwania stanu wojennego, jest wolność działalności gospodarczej ${ }^{17}$. Ograniczenie może zostać zastosowane $\mathrm{w}$ formie nałożenia na przedsiębiorców obowiązku wykonywania dodatkowych zadań, których realizacja jest niezbędna do zagwarantowania bezpieczeństwa lub obronności państwa oraz zapewnienia zaopatrzenia ludności (art. 25 ust. 1 pkt 1 USWoj.). Wojewoda wprowadza powyższe ograniczenia o ile zostały one przewidziane w rozporządzeniu o wprowadzeniu stanu wojennego - w drodze decyzji (art. 25 ust. 2 pkt 2 USWoj.). Zważywszy na wcześniejsze rozważania na temat podmiotów leczniczych, należy skonstatować, że podmioty lecznicze, które należą do kategorii przedsiębiorców, mogą być adresatami tych obowiązków. Na możliwość nałożenia na podmiot leczniczy zadania — w ramach wykonywanej działalności leczniczej — które jest niezbędne do zapewnienia bezpieczeństwa państwa, należy w szczególności spojrzeć przez pryzmat normy art. 6 ustawy z dnia 21 listopada 1967 r. o powszechnym obowiązku obrony Rzeczypospolitej Polskiej ${ }^{18}$. Regulacja ta stanowi o zadaniach Rady Ministrów wykonywanych w kwestiach zapewnienia zewnętrznego bezpieczeństwa państwa i sprawowania ogólnego kierownictwa w dziedzinie obronności kraju. Pośród tych zadań, w kontekście rozpatrywanego zagadnienia, na szczególną uwagę zasługuje „określanie zasad wykorzystania służby zdrowia $[\ldots] \mathrm{w}$ razie zewnętrznego zagrożenia bezpieczeństwa i w czasie wojny" (art. 6 ust. 1 pkt 8 UPOORP). Ponadto Rada Ministrów ma kompetencje do wydania rozporządzenia celem doprecyzowania trybu wykonywania tych zadań, w szczególności gdy idzie o warunki oraz sposób przygotowania i wykorzystania podmiotów leczniczych na potrzeby obronne państwa (art. 6 ust. 2 pkt 8 UPOORP). W myśl powołanej delegacji ustawowej Rada Ministrów wydała rozporządzenie z dnia 27 czerwca 2012 r. w sprawie warunków i sposobu przygotowania oraz wykorzystania podmiotów leczniczych na potrzeby obronne państwa oraz właściwości organów w tych sprawach ${ }^{19}$. Na mocy tego

16 Zob. więcej M. Brzeziński, Stany nadzwyczajne w polskich konstytucjach, Warszawa 2007, s. $32-33$.

17 O wolności gospodarczej zob. więcej w szczególności M. Szydło, Wolność działalności gospodarczej jako prawo podstawowe, Bydgoszcz-Wrocław 2011, s. 53-73; R. Sowiński, Wolność i ustawowa swoboda działalności gospodarczej, Wrocław 2007, s. 80-130.

18 Ustawa z dnia 21 listopada 1967 r. o powszechnym obowiązku obrony Rzeczypospolitej Polskiej, tekst jedn. z dnia 12 maja 2015 r., Dz.U. z 2015 r., poz. 827 (dalej: UPOORP).

19 Rozporządzenie Rady Ministrów z dnia 27 czerwca 2012 r. w sprawie warunków i sposobu przygotowania oraz wykorzystania podmiotów leczniczych na potrzeby obronne państwa oraz właściwości organów w tych sprawach, Dz.U. z 2012 r., poz. 741. 
aktu prawnego wojewodzie przyznana została kompetencja do organizowania, nakładania, sprawowania nadzoru i wykonywania zadań w stosunku do właściwych terytorialnie podmiotów leczniczych - z pewnymi zastrzeżeniami, na przykład w odniesieniu do podmiotów leczniczych będących przedsiębiorcami konieczny jest uprzedni wniosek właściwego miejscowo starosty ( 3 rozporządzenia). Analiza ta daje podstawę do twierdzenia, że podmioty lecznicze mogą wykonywać zadania z zakresu bezpieczeństwa państwa, zatem takie zadania mogą stanowić przedmiot zobowiązania nałożonego przez wojewodę na podmiot leczniczy w czasie stanu wojennego.

\section{KOMPETENCJE WOJEWODY Z ZAKRESU OCHRONY ZDROWIA W STANIE KLĘSKI ŻYWIOŁOWEJ}

Stan klęski żywiołowej wprowadzany jest przez Radę Ministrów z własnej inicjatywy lub na wniosek wojewody w drodze rozporządzenia. Przyczyną ustanowienia może być zapobieżenie skutkom katastrof naturalnych lub awarii technicznych, które noszą znamiona klęski żywiołowej, a także ich usunięcie ${ }^{20}$.

W czasie trwania stanu klęski żywiołowej podmioty lecznicze zobowiązane są do zapobiegania skutkom klęski i ich usuwania. Obowiązki te wykonują w szczególności obok organów Państwowej Straży Pożarnej, Policji i Straży Granicznej. Jeżeli stan klęski żywiołowej został wprowadzony na obszarze więcej niż jednego powiatu wchodzącego w skład województwa, podlegają one kierownictwu wojewody (art. 17 USKŻ).

Podobnie jak w przypadku stanu wojennego, tak też w czasie trwania stanu klęski żywiołowej możliwe jest wprowadzenie ograniczeń wolności i praw czło-

20 Art. 2 ustawy z dnia 18 kwietnia 2002 r. o stanie klęski żywiołowej, tekst jedn. z dnia 20 lutego 2014 r., Dz.U. 2014 r., poz. 333 (dalej: USKŻ). Przez klęskę żywiołową należy rozumieć: katastrofę naturalną lub awarię techniczną, których skutki zagrażają życiu lub zdrowiu dużej liczby osób, mieniu w wielkich rozmiarach albo środowisku na znacznych obszarach, a pomoc i ochrona mogą być skutecznie podjęte tylko przy zastosowaniu nadzwyczajnych środków, we współdziałaniu różnych organów i instytucji oraz specjalistycznych służb i formacji działających pod jednolitym kierownictwem; katastrofa naturalna to: zdarzenie związane z działaniem sił natury, w szczególności wyładowania atmosferyczne, wstrząsy sejsmiczne, silne wiatry, intensywne opady atmosferyczne, długotrwałe występowanie ekstremalnych temperatur, osuwiska ziemi, pożary, susze, powodzie, zjawiska lodowe na rzekach i morzu oraz jeziorach i zbiornikach wodnych, masowe występowanie szkodników, chorób roślin lub zwierząt albo chorób zakaźnych ludzi albo też działanie innego żywiołu; awaria techniczna: gwałtowne, nieprzewidziane uszkodzenie lub zniszczenie obiektu budowlanego, urządzenia technicznego lub systemu urządzeń technicznych powodujące przerwę w ich używaniu lub utratę ich właściwości; natomiast przez cyberprzestrzeń należy rozumieć: przestrzeń przetwarzania i wymiany informacji tworzoną przez systemy teleinformatyczne, określone w art. 3 pkt 3 ustawy z dnia 17 lutego 2005 r. o informatyzacji działalności podmiotów realizujących zadania publiczne (Dz.U. z 2013 r., poz. 235, oraz z 2014 r., poz. 183), wraz z powiązaniami pomiędzy nimi oraz relacjami z użytkownikami. Należy też dodać, że przyczyną katastrofy naturalnej, a także awarii technicznej, mogą być zdarzenia w cyberprzestrzeni oraz działania terrorystyczne (art. 3 ust. 1 i 2 USKŻ). 
wieka i obywatela. Inaczej zaś niż w przypadku stanu wojennego i stanu wyjątkowego, regulując stan klęski żywiołowej, ustrojodawca posłużył się pozytywnym wyliczeniem wolności i praw, które mogą zostać ograniczone. W kontekście przedmiotowych rozważań warto zaznaczyć, że w czasie stanu klęski żywiołowej właściwe organy są władne do wprowadzania ograniczeń w zakresie wolności działalności gospodarczej (art. 233 ust. 3 KRP). Restrykcje te mogą przybrać w szczególności formę:

— zawieszenia działalności określonych przedsiębiorców,

— nakazu lub zakazu prowadzenia określonego rodzaju działalności gospodarczej,

- zakazu okresowego podwyższania cen na usługi danego rodzaju (art. 21 ust. 1 pkt 1,2 i $4 \mathrm{a}$ USKŻ).

Wydaje się zatem, że ze względu na przedstawioną problematykę dotyczącą statusu prawnego podmiotów leczniczych (podmiot leczniczy jako przedsiębiorca), a także fakt, że podmioty lecznicze wykonują działalność leczniczą, która jest kwalifikowaną działalnością gospodarczą (działalnością regulowaną), powyższe ograniczenia mogą znaleźć zastosowanie także w stosunku do nich.

Ograniczenia wolności i praw człowieka i obywatela (w tym wolności gospodarczej) w czasie trwania stanu klęski żywiołowej wprowadza wojewoda, w przypadku gdy stan nadzwyczajny został wprowadzony — jak już podkreślano - na obszarze więcej niż jednego powiatu wchodzącego w skład województwa. Należy podkreślić, że omawiane ograniczenia mogą być przez wojewodę wprowadzane jedynie, gdy zostały przewidziane w rozporządzeniu Rady Ministrów o wprowadzeniu stanu klęski żywiołowej. Rozważane limitacje w obszarze wolności działalności gospodarczej są inicjowane przez wojewodę w drodze decyzji albo rozporządzenia (art. 23 ust. 1 USKŻ).

Wystąpienie katastrofy naturalnej lub awarii technicznej w rozumieniu przepisów USKŻ aktualizuje też obowiązki z zakresu funkcjonowania systemu Państwowego Ratownictwa Medycznego. Otóż w sytuacji ich wystąpienia lekarz koordynator ratownictwa medycznego ${ }^{21}$ przekazuje wojewodzie niezwłocznie informację o konieczności postawienia w stan podwyższonej gotowości podmiotów wykonujących działalność leczniczą (wszystkich lub wybranych) działających na obszarze danego województwa. Lekarz koordynator ratownictwa medycznego ma analogiczny obowiązek w przypadku wystąpienia zdarzenia, którego skutki mogą spowodować stan nagłego zagrożenia zdrowotnego ${ }^{22}$ znacznej liczby osób. Jeżeli

${ }^{21}$ Lekarz działający w centrum powiadamiania ratunkowego albo w wojewódzkim centrum zarządzania kryzysowego - art. 29 ust. 1 ustawy z dnia 8 września 2006 r. o Państwowym Ratownictwie Medycznym, tekst jedn. z dnia 19 kwietnia 2013 r., Dz.U. z 2013 r., poz. 757 (dalej: UPRM); o kompetencjach lekarza koordynatora ratownictwa medycznego zob. też J. Skoczylas, Prawo ratownicze, Warszawa 2011, s. 354-355.

22 Stan polegający na nagłym lub przewidywanym w krótkim czasie pojawieniu się objawów pogarszania zdrowia, którego bezpośrednim następstwem może być poważne uszkodzenie funkcji 
informacje o zagrożeniu uzasadniają interwencję wojewody, wydaje on decyzję administracyjną $\mathrm{w}$ przedmiocie obowiązku pozostawania $\mathrm{w}$ stanie podwyższonej gotowości w stosunku do podmiotów wykonujących działalność leczniczą (kwalifikowanych jak wyżej). Stan podwyższonej gotowości wprowadzany jest celem przyjęcia osób znajdujących się w stanie nagłego zagrożenia zdrowotnego. Warto także zaznaczyć, że wojewoda ma kompetencje do upoważnienia lekarza koordynatora ratownictwa medycznego do wydawania decyzji o nałożeniu na podmioty wykonujące działalność leczniczą obowiązku pozostawania w stanie podwyższonej gotowości. Decyzjom zarówno wojewody, jak i upoważnionego lekarza koordynatora ratownictwa medycznego nadaje się rygor natychmiastowej wykonalności $^{23}$. Jeżeli świadczenia udzielane w związku ze stanem podwyższonej gotowości nie są finansowane przez płatnika (Narodowy Fundusz Zdrowia) - stosuje się odpowiednio przepisy o pomocy w stanach nagłych, zatem gwarantujące świadczeniobiorcy uzyskanie świadczenia, a świadczeniodawcy otrzymanie wynagrodzenia za jego udzielenie (art. 30 ust. 5 w zw. z art. 19 UŚP).

\section{KOMPETENCJE WOJEWODY W ZAKRESIE NAŁOŻENIA NA PODMIOT LECZNICZY OBOWIĄZKU WYKONANIA OKREŚLONEGO ZADANIA}

Na tle niniejszych rozważań na uwagę zasługują niewątpliwie także regulacje UDL, w przedmiocie przyznania wojewodzie kompetencji do nakładania na podmioty lecznicze obowiązków wykonywania określonych zadań ${ }^{24}$. Obowiązki te mogą zostać przez wojewodę nałożone jedynie w stosunku do tak zwanych publicznych podmiotów leczniczych. Adresatem obowiązku może być zatem spółka kapitałowa, w której jedynym albo większościowym udziałowcem bądź akcjonariuszem jest skarb państwa, gdy uprawnienia skarbu państwa wykonuje wojewoda. Ponadto przedmiotowy obowiązek może być nałożony na SPZOZ lub państwową jednostkę budżetową, dla której podmiotem tworzącym ${ }^{25}$ jest wojewoda (art. 38 ust. 1 pkt 1 i 2 UDL) ${ }^{26}$.

organizmu lub uszkodzenie ciała, lub utrata życia, wymagający podjęcia natychmiastowych medycznych czynności ratunkowych i leczenia (art. 3 pkt 8 UPRM).

${ }^{23}$ Zob. więcej E. Fryźlewicz-Chrapisińska, M. Waszkiewicz [w:] Ustawa o Państwowym Ratownictwie Medycznym, red. S. Poździoch, Warszawa 2013, s. 265-280.

24 Analogiczna kompetencja przyznana została również ministrom i centralnym organom administracji rządowej.

25 W rozumieniu przepisów UDL podmiotem tworzącym jest podmiot albo organ, który utworzył podmiot leczniczy w formie samodzielnego publicznego zakładu opieki zdrowotnej, jednostki budżetowej albo jednostki wojskowej — art. 2 ust. 1 pkt 6 UDL.

${ }^{26}$ Zasygnalizowania wymaga, że prawodawca przyznał również jednostkom samorządu terytorialnego kompetencje do nałożenia na podmiot leczniczy obowiązków wykonania określonego zadania, z podobnym zastrzeżeniem ograniczającym jedynie do podmiotów leczniczych $\mathrm{w}$ formie spółek kapitałowych, w których posiadają więcej udziałów lub akcji, a także do SPZOZ-ów lub samorządowych jednostek budżetowych, dla których są podmiotami tworzącymi. 
Pod rozwagę należy poddać kwestię natury prawnej nałożonego obowiązku. Wydaje się, że błędną interpretacją byłoby twierdzenie, że wojewoda ma kompetencje do nałożenia na podmiot leczniczy (kwalifikowany jak powyżej) obowiązku wykonania dowolnie określonego zadania. Jak już wskazano, dany podmiot jest podmiotem leczniczym jedynie w zakresie, w jakim wykonuje działalność leczniczą. Zatem, przykładowo, spółka kapitałowa, która w ramach prowadzonej działalności gospodarczej wykonuje działalność leczniczą i inną działalność usługową, będzie podmiotem leczniczym w zakresie wykonywanej działalności leczniczej i przedsiębiorcą niekwalifikowanym jako podmiot leczniczy w zakresie wykonywanej innej działalności usługowej ${ }^{27}$. Wobec powyższego, skoro wykonywanie działalności leczniczej determinuje określony podmiot jako podmiot leczniczy, należy przyjąć, że określone zadanie, którego obowiązek wykonania może być nałożony przez wojewodę na podmiot leczniczy, winno swym zakresem obejmować jedynie aktywność w ramach działalności leczniczej ${ }^{28}$. Obowiązek może zatem dotyczyć wykonania zadania w przedmiocie udzielania świadczeń zdrowotnych, a także działalności w obszarze promocji zdrowia lub realizacji zadań dydaktycznych i badawczych w powiązaniu z udzielaniem świadczeń zdrowotnych i promocją zdrowia, w tym wdrażaniem nowych technologii medycznych lub metod leczenia (również za pośrednictwem systemów teleinformatycznych lub systemów łączności).

Forma prawna, za pośrednictwem której obowiązek wykonania zadania przez podmiot leczniczy jest nakładany przez wojewodę, może przybrać postać umowy o charakterze cywilnoprawnym albo aktu administracyjnego. W literaturze prezentowane są dwa odmienne stanowiska w przedmiocie rodzaju aktu administracyjnego, który jest właściwy nałożeniu obowiązku. F. Grzegorczyk przekonuje, że nałożenie przez organ administracji publicznej (tutaj wojewodę) rozpatrywanego obowiązku następuje w drodze decyzji administracyjnej, natomiast T. Rek, argumentując, że brakuje wyraźnej podstawy prawnej do wydania decyzji, że idzie o swoiste oświadczenie organu o nałożeniu obowiązku' ${ }^{29}$.

Podkreślić należy, że ustawodawca nie obwarował w żaden sposób skorzystania z wyżej omawianej kompetencji przez wojewodę. Przyczyn możliwości nałożenia obowiązku wykonania określonego zadania na podmiot leczniczy godzi się zatem upatrywać bardzo szeroko. Przesłanką nałożenia obowiązku może być niedobór udzielanych przez podmioty lecznicze na danym terytorium świadczeń zdrowotnych określonego rodzaju, a także sytuacja szczególnego zagrożenia,

27 Zob. więcej na ten temat P. Rataj, P. Pietrołaj, Wykonywanie działalności leczniczej na gruncie nowej ustawy przez podmioty lecznicze, Dodatek specjalny do „Edukacji Prawniczej” 1, 2002, s. 1-28.

28 Tak też T. Rek [w:] M. Dercz, T. Rek, Ustawa o działalności leczniczej. Komentarz, Warszawa 2012, s. 178.

${ }^{29}$ F. Grzegorczyk [w:] Ustawa o działalności leczniczej, red. F. Grzegorczyk, Warszawa 2013, s. 160; T. Rek, op. cit., s. 179. 
skutkująca zagrożeniem zdrowia i życia wielu osób. Wydaje się zatem, że wprowadzenie stanu nadzwyczajnego jest szczególnie uzasadnionym przypadkiem dokonania przez wojewodę zobowiązania, o którym mowa ${ }^{30}$.

Nałożenie przez wojewodę obowiązku wykonania określonego zadania przez podmiot leczniczy implikuje konieczność zapewnienia przez niego środków na pokrycie wydatków związanych z realizacją zadania. Regulacja ustawowa nie wskazuje jednak, czy idzie o uprzednie wyposażenie podmiotu leczniczego w środki zapewniające prawidłowe wykonanie nałożonego zadania, czy wojewoda pokrywa powstałe koszty w sposób następczy, po wykonaniu zadania. Wydaje się zatem, że z racji braku jasnego wskazania przez normę prawną możliwe jest w omawianej sytuacji finansowanie podmiotów leczniczych w obydwu wskazanych formach ${ }^{31}$. W sytuacji gdy zadanie nakładane jest na podmiot leczniczy $\mathrm{w}$ formie odpłatnej umowy, kwestie związane z zapewnieniem środków na pokrycie wydatków zostają zastąpione ustalonym w umowie wynagrodzeniem za realizację zadania. Ponadto wojewoda jest obowiązany do naprawienia szkody, która została poniesiona przez podmiot leczniczy podczas wykonywania nałożonego nań zadania (art. 38 ust. 3 i 4 UDL).

\section{PODSUMOWANIE}

Poczyniona analiza daje podstawę do twierdzenia, że kompetencje wojewody w stanach zagrożenia, w tym w szczególności w stanach nadzwyczajnych, w odniesieniu do podmiotów leczniczych są szerokie. Ponadto daje się zauważyć tendencja do nieokreślania kompetencji wojewody w tym zakresie w sposób precyzyjny. Takie rozwiązanie jest zrozumiałe ze względu na nieprzewidywalność zagrożeń i ich skutków. Kompetencje wojewody jako terenowego organu administracji publicznej winny być $\mathrm{w}$ takich sytuacjach determinowane $\mathrm{w}$ taki sposób, aby nie krępować podejmowania niezbędnych działań zapobiegających zagrożeniom, a także usuwających ich skutki. Warto również wyeksponować, że kompetencje wojewody w omawianym zakresie zostały uregulowane w wielu aktach prawnych, nie ograniczając się jedynie do ustaw traktujących o stanach nadzwyczajnych.

30 Por. ibidem.

31 Inaczej F. Grzegorczyk, którego zdaniem posłużenie się przez ustawodawcę sformułowaniem ,na pokrycie wydatków związanych z wykonaniem tych zadań” przesądza o formie dokonanej, zatem pokrycie wydatków winno następować po wykonaniu przez podmiot leczniczy nałożonego zadania, idem, op. cit., s. 161. 


\section{COMPETENCES OF A VOIVODE IN RELATION TO MEDICAL SUBJECTS IN STATES OF EMERGENCY}

\section{Summary}

The aim of this article is to present competences of a voivode, who is one of the local public administration bodies, in relation to specific subjects - medical subjects. These competences are considered against the background of regulations of states of emergency. Furthermore, the article undertakes the analyses of competences of a voivode, which are related to Healthcare Institutions Law. 